\title{
Descriptiong of new COLEOPTERA of the United States, with notes on known species.
}

BY GEO. H. HORN, M. D.

CICINDELA, Linn.

C. puritana, n. sp.-Elor gate, brownish æneous. Head and thorax sparsely pilose with white hairs. Labrum white, rounded in front with angles obtuse but moderately prominent, occiput punctured and finely rugulose, vertex finely strigose. Thorax slightly broader than long, sides feebly rounded, apical, basal and median grooves moderate. Elytra parallel, twice as broad as long; a median basal white spot, lałeral margin narrowly bordered with white, with oblique subhumeral branch suddenly mucronate at tip, a median slightly sigmoid fascia, somewhat confused at middle, and an cblique short subapical lunule. Surface moderately densely punctured.

Male.-Elytra near apical, three fourths distinctly sinuate and obliquely narrowed to tip which is moderately prominent, distinctly serrulate and spinulose at suture.

Female.-Elytra at three fourths deeply sinuate and with a strong acute tooth, obliquely narrowed to apex which is finely serrulate, sub-truncate and at suture slightly prominent. Body beneath smooth shining, sparsely pilose, and with metallic bluish-green lustre. Trochanters rufous, femora cupreo-æneous, tibiæ reddish testaceous bluish at tip. Tarsal joints at proximal end reddish testaceous. Length .46 inch; $11.5 \mathrm{~mm}$.

This species must be referred to the group with cuprascens, macra, etc. It has exactly the color of the latter species and also the markings except that the median band is less sinuous. It differs also in having the $q$ somewhat broader and less parallel, and the elytral sculpture rather coarser, the sinuation of the elytra deeper and the tooth stronger and more acute in $\$$ and more decidedly truncate at apex. The thorax in macra, is longer than broad and in the present species slightly broader than long; cuprascens, differs primarily in color and the female has the sutural angle at apex distinctly retracted and the male has the apical margin serrulate to the sinuation while the present species the margin is serrulate near the sutural margin only. From the above comparisons it will be seen that the species oceupies an intermediate position to the two above cited, having the color and sculpture of one and the sexual characters very nearly of the other.

Specimens were collected in southern New Hampshire and at Spring. field Massachusetts, and sent me by Mr. S. Henshaw of Boston.

CHLENIUS, Bonelli.

C. viduus, n. sp.-Head oval, black with a slight tinge of purple, coarsely punctured more densely over the eyes and with a broad impunctured space from the vertex to the front. Antennæ deep black, basal joint reddish-yellow. Parts of mouth deep black. Thorax black with tinge of purple, densely and rather coarsely punctured, median line finely impressed, basal impressions 
small, faint; as broad at base as long, at apex scarcely a third narrower, sides gradually rounded and slightly broader behind the micdle and very slightly narrowed to the basal angles which are obtuse. Elytra slightly broader behind the middle, somewhat broader at base than the thorax and obtuse at apex; color black, at margin slightly purple; surface sparsely clothed with fine, short, ferruginous hairs, finely striate, striæ with distant punctures, intervals densely punctato-granulate. Body beneath black, shining, sparsely punctured. Femora reddish-yellow sparsely punctured, coxæ and trochanters black, hind trochanters at base only blackish. Tibiæ and tarsi deep black with a slight tinge purple. Length .68 $\delta$ inch; $15.5-17 \mathrm{~mm}$.

This species approaches laticollis, in color and general aspect and augustus, in form of thorax. It differs from all our species in the black antennæ and trophi and the femora and tibiæ being of dissimilar color. The elytral striæ are finer than in laticollis, but the granules rather coarser. The thorax is rather more finely punctured, at least not so apt to become confluent.

For an opportunity of examining this species I am indebted to Dr. S. V. Summers, of St. Louis, who kindly placed one at my disposal. It is very rare, only two specimens being known, taken in high sandy places in Missouri probably near St. Louis.

C. orbus, n. sp.-Color black, opaque with very faint tinge of purple. .Body beneath black, more shining and faintly bluish-iridescent. Legs black. Head moderate, oval; occiput sparsely punctured vertical and frontal regions smooth, at the sides sparsely punctured and with longitudinal furrows very indistinct: eolor black with distinct purple tinge. Antennæ piceous at base becoming brownish toward the tip; palpi piceous, at articulations and tip of last joint piceo-rufous. Thorax nearly flat moderately convex across the apex, base about one-tenth broader than the length, apex nearly one-third narrower than the base. Sides moderately rounded, broadest slightly behind the middle and then scarcely narrowed to base, hind angles obtuse. Surface evenly punctured punctures rather coarse and not densely placed, median sulcus faint, abbreviated at either end, basal impressions shallow but extending one-third the length of thorax. Elytra oval broadest at middle, length to breadth as one and a half is to one; color black, very sparsely clothed with short brownish hairs; striæ fine but with rather large punctures placed at a distance from each other nearly equal to half the width of an interspace; interspaces sparsely and finely punctulate. Body beneath black shining, parapleuræ sparsely punctured, sterna smoother; abdomen with very sparse punctures and slightly wrinkled. Legs black shining, femora nearly smooth. Length .65-.68 inch; 16-17 mm.

Occurs in central and western Texas probably also in the adjoining regions of Mexico.

Resembles in form rufipes var. brevicollis, very accurately, while its sculpture (excepting the coarser punctures of the striæ) is very nearly that of fusicornis.

This species has been a long time in our cabinets and I have, until 
the present, hesitated to name it. I cannot find any description fitting it in Chaudoir, Dejean or Chevrolat nor any American species either North or South, to which reference is made in the Catalogue of Gemminger and Harold, with which it agrees.

c. alternatus, n. sp.-Black, feebly shining, head and thorax with a slight reddish bronze; beneath and legs black. Head shining with slightly metallic reddish bronze, impunetured and slightly wrinkled, longitudinal impressions deeper in front; antennæ and parts of mouth black. Thorax one-fourth wider at base than long, at apex narrower than the length, sides moderately rounded and slightly narrowing at base; a median broad but shallow sulcus, containing the median fine line, on each side of which is fa row of very coarse punctures extending to the anterior margin ; basal impressions broad densely and coarsely granulately punctured and with a few short hairs; surface between median sulcus and margin with a few large irregularly placed punctures; lateral margin slightly explanate and reflexed, with coarse punetures; color of thorax reddish bronze with a tinge of green in the impressions. Elytra broadly oval, depressed, black sub-opaque, striæ replaced by rows of very coarse punctures, interspaces moderately convex, the third, fifth and seventh more distinctly elevated, surface densely and rather coarsely granulately punctured clothed with short, inconspicuous, brownish pubescence. Body beneath black shining, parapleuræ and abdomen sparsely punctured, the latter also sparsely pubescent. Legs black, femora with a few punctures with short setæ. Length .50 inch; $12.5 \mathrm{~mm}$.

This species reproduces the form of niger but has rather broader elytra and differs from that species by so many characters that it is not worth while to recapitulate them.

One specimen is before me obtained by Dr. Leconte, from the British Museum in exchange. Collected by Mr. Bourgeau, in the Sackatchewan region.

\section{ANOPHTHALMUS, Sturm.}

A. tepuis, n. sp.-Pale rufo-testaceous, shining. Head slightly darker in color, oval, and areuately biimpressed. Thorax broader than the head, slightly longer than broad and sinuately narrowing to hind angles which are exactly rectangular; median line distinctly impressed in its entire length, basal impression deep; base of thorax truncate. Elytra elongate oval, feebly convex, at base slightly flattened; two-thirds longer than broad, humeri obtusely rounded; surface with feeble traces of striæ and three dorsal setigerous punctures on each elytron, in or nearest to the position of the third stria. Body beneath similar in color to the upper surface, legs somewhat paler. Length .18.24 inch ; $4.5-6 \mathrm{~mm}$.

Three specimens of this species were collected by Prof. E. D. Cope, onc of the most untiring explorers of the caves of our country, in Wyandotte Cave in Southern Indiana.

This species is closely allied to Menetriesi, Motsch (angulatus, Lec.) but differs by its more elongate and less robust form and less convex surface. The elytra are smoother and with very feeble traces of striæ. 
The two species differ especially in the form of the hinder thoracic angles and base of thorax. In Menetriesi, the angles are acute, slightly prominent externally and the base of the thorax slightly prolonged, while in the present species the angles are strictly rectangular and the base truncate. This species must be placed near the one just cited in my table of our species (Trans. Ent. Soc. Phil. 1868, p. 126) in which however a clerical error occurs, in the first line the word "elytra" should be used for "thorax". Two species have been deseribed by by Motschulsky that have not been recognised in this country striatus and ventricosus, (Etudes Entom. 1862, pp. 41, 42) both are small species, the former with deeply punctured striæ and the latter with faint ly punctured striæ, both have the hind thoracic angles rectangular and in the first species slightly produced.

The new species above described is the most slender in form of any in our cabinets.

A. eremita, n. sp.-Pale rufo-testaceous feebly shining. Head oval, areuately biimpressed impressions moderately deep, intervening space feebly convex. Thorax wider at widest portion than long, sides moderately rounded in front gradually narrowed to base hind angles rectangular, base truncate and as wide as length of thorax; disc feebly convex, median line distinctly impressed, basal transverse impression moderate. Elytra oval, less shining than thorax and sparsely clothed with very short erect pubescence; striæ obsolete; three dorsal punctures on the line of the third stria. Length .20 inch; $5 \mathrm{~mm}$.

One specimen of this species was collected with preceding in $\mathrm{Wy}$ andotte Cave, by Prof. Cope.

The only species with which it might be confounded is that previously described by me under the name pusio, and although differing very notably on comparison in their general aspect, the points of difference are not easily made plain in a description. The present species is in all respects broader and less depressed without being convex as in Menetriesi; the thorax is broader, less narrowed behind and the sides more rounded. The elytra are less shining and the pubescence more distinct although in both species the pubescence can only be observed by holding the specimen between the eye and the light and then only with a good power. In the three species at the head of the accompanying table, no signs whatever of pubescence can be observed The elytral striæ are here also entirely obliterated, faint traces are discernible only at the base. The basal margin is not prolonged. The few remarks on the comparison of tenuis with the two as yet unknown species described by Motschulsky apply equally to this one. 
Independently of the characters noted in a preceding short review (Trans. 1868, p. 126) others, probably more important may be found to distinguish our species.

Penultimate joint of maxillary palpi longer than the last joint.

Base of elytra obliquely prolonged; thorax much longer than wide, hind angles rectangular, base truncate; body glabrous

Tellkampfi.

Penultimate joint equal to last or even slightly shorter.

Elytra shining not pubescent; thorax longer than wide.

Hind angles of thorax strictly rectangular, base squarely truncate. Elytra elongate oval, feebly convex, striæ obsolete. Form slender...................................................................tenuis.

Hind angles acute, slightly prominent, base distinctly prolonged at middle.

Elytra broadly oval, more convex, striæ moderately deep and punctured. Form robust..................................................enetriesi.

Elytra sub-opaque, distinctly pubescent; thorax as wide or wider than long. Elytral base never obliquely prolonged.

Sides of thorax gradually narrowing to base, scarcely sinuate, hind angles rectangular or nearly so but never acute and prominent.

Thorax at base as wide as long.................................... eremita.

Thorax at base narrower than long; at widest portion not wider than long.

pusio.

Sides of thorax sinuately narrowing to base, hind angles acute prominent outwardly. Elytra very distinctly pubescent.... pubescens.

SUPHIS, Aubé.

S. lineatus, n. sp.-Elongate oval, more obtuse in front; color dark yellowish testaceous, shining, each elytron with four black vittæ. Head, yellowish smooth impunctured, with darker space at occiput. Thorax more than twice as broad at base as long, yellowish with darker discal space and with a sinuous row of moderate punctures in front of basal margin behind which are smaller ones sparsely placed. Elytra convex gradually narrowed to apex, yellowish, with seven stripes on the elytra conjointly, as follows; a common sutural stripe extending from apex to base, a second extending from the base becoming slightly arcuate near its end joining the sutural a short distance from the apex, a third extending from base two-thirds the length of the elytra, a fourth near the margin starting at the first third and nearly attaining the apex, and usually also a small linear spot in the humeral region; surface coarsely but sparsely punctured, punctures irregularly arranged, and with an indistinet row of coarser punctures near the outer edge of the second black stripe and parallel with but somewhat distant from the basal margin. Body beneath piceo-testaceous, shining, penultimate and preceding segment of abdomen with a tranverse line of coarse punctures. The sternal plate coarsely punctured especially in front. Length .12 inch; $3 \mathrm{~mm}$.

Rather more elongate than bicolor and transversely more convex. Easily known by its coloration.

Specimens were sent me from Cape San Lucas, Lower California, and were collected by Mr. Wm. M. Gabb. 


\section{LACCOPHILUS, Leach.}

L. quadrilineatus, n. sp.-Elongate oval, more obtuse in front; color pale yellowish testaceous, elytra at apex pellucid, and slightly obliquely rounded. Head pale testaceous. Thorax similar in color slightly sinuate at base on each side and at middle obtusely prolonged. Elytra pale testaceous, suture narrowly margined with black not attaining the apex, dise with four black lines on each elytron near the suture not attaining the apex and interrupted behind the middle by a large irregular black patch with a small lobe extending from its outer distal angle toward the margin. Body beneath darker than the upper surface, legs very pale testaceous. Length .24 inch; $6 \mathrm{~mm}$.

This is the only species known to me from the American continent with the ornamentation consisting of black lines.

Specimens were purchased by me from G. W. Belfrage, who coliected them in central Texas.

Laccophilus pictus; Cast., was also collected in the same region as the Suphis, and others have been sent me from Texas. The species should therefore be added to our list.

\section{COLYMBETES, Clairv.}

C. inæqualis, n. sp.-Elongate oval, broader behind the middle. Head black with vertical rufous spot, and anterior margin pale yellow, very finely and densely punctured. Thorax yellowish or brownish with median transverse band and narrow margin at middle of base black, surface intricately and confluently lined and in the intervals punctured, lines obsolete at margin which is densely and finely punctured with a few coarser punctures intermixed. Elytra brownish sometimes paler, margin paler than disc; surface sculptured with transverse lines more deeply graven at the basal two-thirds in which region the surface is sub-opaque from the intervals between the lines being scabrous; apical third more shining. Body beneath black shining, surface finely transversely strigose, strigæ becoming longitudinal at the first two abdominal segments and at the sides of the others, and at the middle of the segments the lines are nearly transverse but very distantly placed. Legs pale, femora piceous; legs sometimes entirely black. Length .66-.70 inch; $16.5-17.5 \mathrm{~mm}$.

There can be no difficulty in distinguishing this species from all the others by the peculiar sculpture. Not only are the transverse lines at basal two-thirds deeper but they are closer together than those at the apex. In exaratus the lines at base are rather deeper than those at apex but they are equally distant, and the intervals are not roughened on top as in the present species. Its position in the series is near longulus.

Occurs in north eastern California and Oregon.

Colymbetes (Scutopterus) coriaceus, Cast., has been collected by Mr. Johnson Pettit, at Grimsby, Canada, and both male and female specimeas placed in my cabinet. 
HYDROPHILUS, * Geofrr.

H. quadristriatus, n. sp.-Elongate oval, more attenuate in front, black with slight olivaceous tinge; surface densely, finely and equally punctured. Head with sigmoid of row coarser punctures on each side, meeting at the vertex. Antennæ and palpi testaceous. Thorax with a small fovea on each side near the anterior margin within the position of the eyes, and an angulate row of punctures on each side near the middle and a few coarse punctures irregularly disposed. Elytra with four striæ of moderate punctures, two striæ sutural, extending nearly from base to apex, enclosing at base a short scutellar row; two striæ subhumeral obliterated at base and extending nearly to apex, becoming confused and extending toward the inner rows. Body beneath black, opaque and pubeseent, abdomen with a row of brownish patches at the sides. Legs pale testaceous, femora at base and tarsi black. Length .38 inch; $9.5 \mathrm{~mm}$.

Resembles lateralis in form but is more narrowed before than behind. The elytra are evenly punctured and the body along the median line moderately convex. It differs from all our species by the four striæ of punctures on each elytron. The outer two rows correspond with an eighth and ninth while traces of a third, fourth and fifth are evident at base.

Collected by Prof. Verrill, near the sea coast of New Jersey.

PHYTOSUS, Curtis.

P. littoralis, n. sp.-Head brownish testaceous, moderately shining, sparsely clothed with yellowish hairs, front feebly concave; parts of mouth and antennæ testaceous, the latter darker at tips. Thorax paler than the head, as broad as long, disc depressed, sides strongly rounded in front, behind the middle sinuate, base truncate feebly emarginate at middle, and slightly broader than half the width of thorax at middle; surface sparsely punctured and pubescent. Elytra pale testaceous, sparsely punctured and pubescent, short, sides strongly divergent behind, body apterous. Abdomen elongate oval broader behind the middle, shining and very sparsely pubescent. Legs pale testaceous. Last segment of abdomen $\delta$ slightly prolonged at middle, and sinuate on each side. Length .08 inch; $2 \mathrm{~mm}$.

The male resembles in its sexual characters $P$. balticus, Kraatz, but the median prolongation of the last abdominal segment is broader. The penultimate segment is subcarinate along the median line posteriorly. The mandibles are more prominent than in our California species.

One specimen collected by Prof. A. S. Verrill, on the sea coast of New Jersey.

* Note. - This and the next species were obtained from a small collection made on the Jersey coast and descriptions and a list of the other species prepared for Prof. Verrill. Owing to the delay in publication and desirability of keeping descriptions of new species close together and not widely scattered in many journals, permission has been obtained to present them in these Transactions. 


\section{QUEDIUS, Leach.}

Q. spelæus, n. sp.-Pale rufo-testaceous shining. Head broadly oval, smooth shining slightly impressed between the eyes in front; two punctures bearing short setæ in front of the eyes, another at the side of vertex, two at the side of head behind, hind angle of head slightly pubescent. Eyes not large, nearly round and prominent. Antennæ moderately stout, one-half longer than the head, first joint nearly as long as the second and third together, the third onehalf longer than the second: joints 4-10 gradually but feebly stouter, cylin-

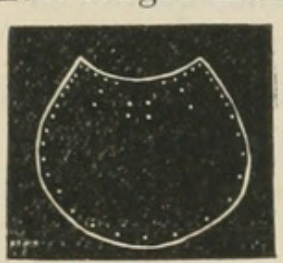
drical and scarcely longer than wide, joint 11 longer than the preceding and sub-acute at tip. Thorax slightly broader than the elytra, sides distinctly explanate, broader than long, em arginate in front anterior angles subacute, sides and base broadiy rounded formıng nearly a circle less the emargination in front; surface smooth shining and with punctures arranged as follows: a dorsal series of two punctures moderately distant from the anterior margin, a lateral oblique series of three or four punctures, one puncture being within the line of the lateral but not belonging to the dorsal series; a marginal row of moderately large punctures close to the lateral margin extending along the base, the punctures being more distant in the latter region. Prosternal process behind the coxæ corneous. Scutellum smooth shining. Elytra slightly longer than the thorax, rather densely and moderately coarsely punctured and sparseJy clothed with short yellowish pubescence. Abdomen moderately elongate, longer than the head, thorax and elytra together, slightly narrowed to apex, moderately punctured but less densely than the elytra, above and beneath sparsely clothed with brownish hairs. Body beneath and legs similar in color to the upper surface. Length .46-.50 inch; $11.5-12.5 \mathrm{~mm}$.

Abundantly distinct from all our species by the color and thoracic punctures. The sides of thorax are more explanate than any of our species except explanatus, Lec.

Two specimens werc collected by Prof. E. D. Cope, a short distance within the mouth of Wyandotte Cave in southern Indiana.

GLYPTOMA, Er.

G. brevicristatum, n. sp.-Brownish, opaque. Head in front hemihexagonal sides slightly arcuate; with two short carinæ on the vertex and a slight cari-
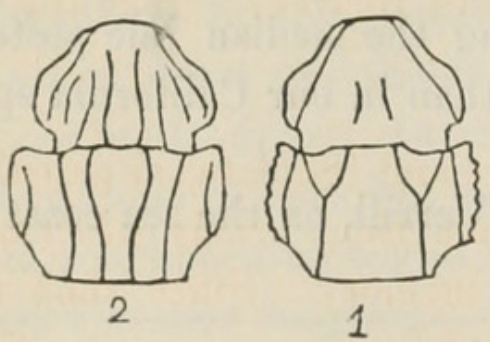
na extending from the hind angle of the head, close to the margin, obliquely inwards and forwards to the frontal margin. Thorax broader than long, dise bicostate, eostæ distant and bifurcate at apical margin; near the sides two costre, the inner extending, from anterior margin and joining the side one fifth from apex the outer earina nearer the margin and short; sides of thorax straight, suddenly sinuate at base, anterior angles moderately prominent, margin slightly erenulate. Elytra subquadrate, dise five costate, the second costa faint; interspaces finely granulose. Abdomen opaque. Body beneath less opaque. Legs ferruginous brown. Length .10 inch; $2.5 \mathrm{~mm}$.

Resembles our common costale, but differs in the sculpture of the 
head and thorax. In the eut the outer short earina of thorax is accidentally omitted.

One specimen collected by myself at Camp Grant, Arizona. In the accompanying cut, fig. 1 , is $G$. brevicristatum, and fig. $2, G$. costale.

Pscudopsis sulcatus, Nm. Specimens of this species have been taken rather abundantly near Grimsby, Ontario, by Mr. Johnson Pettit. On comparison of these with a type from England I find no specific differences.

\section{SAPRINUS, Er.}

S. æneipunctatus, n. sp.-Black opaque. Form short robust. Head retracted, front with few punctures, transverse ridge faint. Thorax twice as broad as long, sides feebly rounded and gradually narrowed anteriorly; surface densely punctured at the sides, smoother and less densely punctured at middle. Elytra very densely and coarsely punctured over the entire surface, humeri with small smooth space; punctures brilliantly æneous at bottom. Striæ almost entirely obliterated, the first dorsal long, second, third and fourth very short, the latter united by faint arch with the nearly obsolete sutural; humeral stria nearly obsolete, one subhumeral moderately distinct. Anterior tibiæ five-den tate, the lower three teeth strong; hind tibiæ triseriately strongly spinulose. Prosternum acutely carinate. Body beneath black shining, coarsely punctured at the sides, smoother at middle. Pygidium convex, densely punctured and nearly vertical. Femora smooth. Length .12 inch; breadth .10 inch; $.3-2.5$ $\mathrm{mm}$.

This species must be referred to Marseul's group V, and Leconte's group 9 near patruelis and lucidulus. It resembles in form a miniature sulcifrons, and is more coarsely and densely punctured than any species in our fauna. Resembles also bigemmeus, Lec., but may be readily known by the compresso-carinate prosternum and the absence of the well defined small scutellar spaces of that species, although some specimens of æneipunctatus, have scutellar spaces slightly more convex than the rest of the surface and somewhat smoother, although punctured and rugose.

Several specimens presented by Mr. James Behrens; from the sea coast near San Francisco.

OTHNIUS, Lec.

The above genus was founded by Leconte and incicated as a distinct family, Class. Col. N. A. p. 102, at the same time briefly describing one species and indicating a second from memory. Since then two others have been described in our fauna, as follows:

0. fasciatus, Bland. Proc. Ent. Soc. 1864, 253. Virginia.

0. lugubris, Horn, Trans. Ent. Soc. 1868, 132. Oregon and also

0. mexicanus, Horn, loc. cit. 133, from Mexico.

Previously however Mr. Pascoe, described a genus under the name 
Elacatis, founded on a species from Borneo to which the appropriate name delusa was given, and referred to the family Melandryidæ in consequence of its heteromerous tarsi. In the Annals and Magazine of Natural History, for 1871, Mr. Pascoe has corrected the error apparently at the suggestion of Dr. Leconte. An examination of all the specimens before me shows the tarsi to be heteromerous in both sexes.

The generic name suggested by Pascoe has priority and must be adopted.

The following species is new.

E. longicornis, n. sp.-Dark brownish testaceous, shining, sparsely clothed with greyish hairs. Form moderately elongate, subdepressed parallel. Head large, densely punctured, darker in color than the rest of the body. Antennæ as long as half the body, slender, scarcely clavate, joints gradually broader to tip; third joint very long, as long as the three following together ; color yellowish. Thorax slightly broader than long, sides parallel in front sinuate near base, hind angles slightly prominent, margin rounded, sub-acute only near the base; surface moderately punctured. Elytra brownish, paler than the thorax ornamented with irregularly placed pale spots; surface punctured rather closely but irregularly. Body beneath piceous shining, sparsely punctulate. Length .12 $\delta-.18 q$ inch; $3-4.5 \mathrm{~mm}$.

Differs from all our species by the unusually long and very feebly clavate antennæ. In the male only do the last three joints exhibit any increase of size over the preceding and then very faintly. The form of body is nearly that of fasciatus and is much less elongate than any of our other species. There is a possibility that this species may be identical with the one for which the name guttulatus, Lec. was suggested.

Two specimens from near Fort Yuma, California.

BRADYCINETUS n. g.

This name is suggested in place of Amechanus (preoccupied in the Cerambycidæ), Trans. Am. Ent. Soc. 1870, 48, including our species long known under the name of Athyreus.

CYCLOCEPHALA, Latr.

There is hardly a genus among our Lamellicorn beetles presenting species more closely allied in all their prominent specific characters. The difficulty of naming any of our forms from the descriptions at hand as well as with the various tables presented, has prompted me to seek new, more definite and less comparative characters. I believe all the species in our fauna to be hairy when fresh, consequently this means of grouping them is of no value, while the form of the clypeus although differing among the species, does not present that 
range of variation affording an exact means of description. The following table is presented prepared from a study of my own and Leeonte's specimens. The determinations of the species are those made by Leconte and the names in all cases refer to the same species intended by him in "New Species", p. 79.

Antennæ 9-jointed.

Anterior claw $\delta$ slightly cleft behind tip; palpi not impressed.......manca. Antennæ 10 -jointed.

Anterior claw $\delta$ not eleft.

Prosternum in front compressed, acute at summit; palpi impressed seditiosa.

Prosternum convex not carinate.

Last joint of maxillary palpus impressed puberula

Last joint of maxillary palpus cylindrical not impressed....nigricollis. Anterior claw $\delta$ cleft sometimes very slightly.

Antennal club $\delta$ shorter than the others joints together.

Pygidium sparsely punctured, hairs short... immaculata.

Pygidium coarsely punctured, rugulose, nairs long.................hirta. Antennal club $\delta$ longer than the other joints taken together.

Last joint of maxillary palpus cylindrical. villosa.

Last joint of maxillary palpus fusiform longula. Anterior claw $\delta$ deeply divided elegans.

The above table is founded on the sexual characters of the male primarily. It is nearly impossible to prepare a table of any value for the other sex. The females are readily known by all their claws being similar and the spurs of the hind tibiæ shorter, broader and stouter than the male.

C. manca, Lec. Proc. Acad. 1866, p. 382.

In addition to the characters given by Leconte, the mentum and ligula are broadly and deeply grooved at middle, the latter deeply em. arginate in front and the angles prominent and divergent. The anterior claw of front tarsus of $\hat{\delta}$ is thick and distinctly cleft behind its tip and on the posterior edge. It is our largest species and may form a new genus.

C. seditiosa, Lec. New Species, p. 79.

This is one of our most elongate species, and may be known by the anterior claw not cleft and the prosternum in front of coxæ strongly compressed and acute at summit. The last joint of maxillary palpus is distinctly impressed. The upper tibial teeth of the anterior pair are very short and obtuse. The antennal club is long and equals all the other joints taken together. The elypeus is nearly smooth. 
C. puberula. Lec. New Species, p. 80 .

Resembles a Melolonthide of the Trichesthes group, and is our smallest species. The anterior $\hat{\delta}$ spur is proportionately more slender than in most of our species. The prosternum in front of coxæ is broadly convex and punctured and not carinate as in the preceding species. Antennal club long.

C. nigricollis, Burm. Handbuch, V, p. 50 ; robusta, Lec. New Species, p. 79.

The synonymy has been determined by types sent me by Dr. Leconte from Europe. It is the only one of our species in which the elytra are brownish testaceous. The type of robusta is rather broader than the other specimens and the difference is probably owing to the specimen having been accidentally flattened. The antennal club is here also long and the last joint of maxillary palpus with but the merest trace of an impression so distinctly visible in the preceding. No difficulty need be found in distinguishing the three species forming this sub-group.

C. immaculata, Oliv. (Melolontha) Ent. I, 5, p. 29, pl. 8, fig. 95; Burm. (Cyclocephala) Handb. V, p. 53 ; nigrifrons, Panzer (Melolontha) Faun. Am. Bor. Prod. 1794; lurida, Bland. Proc. Ent. Soc. 1863, p. 354.

This is our most abundant and widely diffused species and is found from Illinois westward and southward extending even to Arizona and Mexico. It is consequently variable, those from the Texas region being broader and more robust and usually with a more decided surface sculpture. This species is very closely allied to the following but may be known by the pygidium being more feeble punctured and the hairs very short. The hairs of the surface, when the specimen is fresh, are also shorter and much less abundant. In immaculata, the last joint of maxillary palpus is very feebly impressed and the posterior elevations of the prosternum distinctly visible when viewed from the front.

C. hirta, Lec. Proc. Acad. 1861, p. 346.

The prosternal elevation behind the coxæ is much shorter and more obtuse at tip than the preceding species and scarcely visible when viewed from in front. The maxillary palpi have the last joint feebly impressed. This species is widely distributed in California. The specimens from the region of Fort Yuma are more elongate and the hairs more deciduous.

C. villosa, Burm. Handb. V, p. 54.

Closely allied to the preceding. The male has the antennal club 
longer than all the other joints taken together and last joint of maxillary palpus feebly impressed and nearly cylindrical. Harold (Catalogus, 1241) place this species in synonymy with Melolontha angularis Knoch, Neue. Beitr. I, p. 89. The description does not seem to be applicable to our species.

C. longula, Lec. New Species, p. 79.

This is our most elongate species and has the eyes more convex and apparently larger than any other in our fauna. The antennal club is much longer than all the other joints taken together, and the last joint of maxillary palpus fusiform and rather deeply impressed. The prosternum in front of $\cos æ$ is compressed but less acutely carinate than in seditiosa.

C. elegans, n. sp.-Moderately elongate, rufo-castaneous, elytra yellowish testaceous. Head sparsely punctured feet black clypeus hemi-hexagonal brownish, nearly truncate in front, anterior angles obtusely rounded, sides slightly arcuate, margins feebly reflexed. Thorax sparsely punctured, sides moderately rounded and gradually broader to base, hind angles broadly rounded color rufo-castaneous. Elytra yellow testaceous, with coarse punctures arranged in nearly regular rows. Body beneath and legs castaneous. Posterior prosternal protuberance distinctly visible, obtuse at tip and transversely emarginate, prosternum in front compressed not acutely carinate. Antennal club short, last joint of maxillary palpus fusiform and impressed. Anterior claw of anterior tarsus $\delta$ deeply divided, the portions widely divergent. Length $\mathbf{. 4 6}$ $\delta-.54$ inch; $11.5-13.5 \mathrm{~mm}$.

Two specimens from Lower California and one from Indian Territory. Abundantly distinct from all our species in its color and the form of the anterior tarsal claw.

COTALPA, Burm.

C. consobrina, n. sp.-Sides of thorax more feebly arcuate and slightly explanate at hind angles margin broader and more distinctly reflexęd. Elytra relatively longer and less rounded on the sides. Mandibles with a broad tooth beneath from the middle of the free edge in front. Tarsi $\delta$ very stout, anterior tarsi with joints broader than long, the first joint not longer that the second, last joint finely strigose at lowor margin. Apical tooth of anterior tibiæ short. Length .78-.90 inch : $20-23 \mathrm{~mm}$.

Closely allied to lanigera, in color and sculpture but more elongate and less robust.

All our species (puncticollis, Lec. is not before me) have the mandibles laminiform and the tarsal joints longer than wide and the first joint as long as the two following. The present species has the mentum broadly rounded in front and in all the others it is emarginate and in granicollis deeply impressed.

Occurs at Fort Whipple, Arizona. 
Since the publication of Cotalpa ursina, (Trans. Ent. Soc. 1837, 158 ) and the accompanying table of our species I have found that the characters therein made use of are not by any means constant and therefore not to be relied on in separating the species. The mandibles when widely opened afford a more certain indication than any other organ, as may be seen in the following table.

Mandible nearly straight on outer side (pl. III, fig. 30.)

Mandible with triangular lobe beneath (fig. 30,a); body of uniform yellowish eolor; thorax faintly punctured.................consobrina, Horn.

Mandible broadly rounded on outer edge (figs. 28, 29, 31.)

Mentum nearly flat, very feebly emarginate in front.

Mandible faintly toothed within (fig. 31); thorax sparsely punctured and similar in color with the elytra, yellow.... lanigera, Linn.

Mandible with long tooth within (fig. 28) thorax coarsely punctured and bluish-black; elytra reddish-yellow.... ursina, Horn.

Mentum concave in front and deeply emarginate.

Thorax with large deep punctures; elytra yellow.........pnncticollis, Lee.

Thorax densely and confluently punctured; elytra nearly red

granicollis, Hald.

The last two species have the outline of the mandible when viewed directly in front sinuous with the inner angle deflexed. The mentum of consobrina has the sides less rounded than in any other of our species and the anterior margin bisinuous, the middle being as prominent as the angles; the surface is nearly flat but with a ridge extending from the base of the palpi inward and backwards in an arcuate manner becoming gradually fainter behind.

OSMODERMA, Lepell.

0. socialis, n. sp.-Castaneous shining, head and thorax black, the latter reddish or greenish bronzed. Head black, densely and finely rugose, vertex slightly concave, frontal margin strongly reflexed, in front of eyes a broad triangular hotn with the hinder edge sinuous. Thorax one-fifth broader than long, broadest at anterior third, sides strongly rounded in front to anterior third then gradually narrowed to base which is as broad as the thorax is long; hind angles obtusely rounded, base with broad lobe at middle; dise with median broad sulcus broader behind, limited on each side by obtuse ridges which gradually approximate in front, and end each in a rather sudden but small elevation ; on each side an obtuse elevation between the termini of the ridges and the strongly rounded portion of the side; surface evenly and sparsely and not coarsely punctured. Scutellum with median impressed line, sparsely punctured between the elytra and densely under the thoracic lobe. Elytra but slightly longer than broad, finely wrinkled and coarsely punctured. Body beneath sparsely pubescent, black, terminal segments of abdomen piceo-rufous.

Female.-Vertex flat, front with arcuate impression between the eves, anterior margin not reflexed, surface coarsely scabro-punctate. Thorax similar in form to the male but less broad anteriorly, middle with broad, shallow impression; 
surface more coarsely and densely punctured. Length $1.25-1.08 \delta$ and $1.12 \uparrow$ inch; $32-27 \mathrm{~mm} \delta$ and $28 \mathrm{~mm} \uparrow$.

This species in its elytral sculpture is exactly intermediate between our other two species eremicola and scabra. The surface of the thorax is sculptured after the style of the latter species but in a more exaggerated degree. The anterior margin of the front is more reflexed than either. It may distinguished at once from either species by having the prosternum in front of the coxæ less convex and strongly, transversely wrinliled, as well as broader. The color of the surface varies somewhat. There is at times only the ground color (castaneous) visible, while others have a distinct greenish lustre. Its form is broader and more robust than eremicola.

CREMASTOCHILUS, Knoch.

During an examination of my specimens of the above genus two were found that could not be referred to any described species and the present opportunity is made use of to present to students of our fauna the results of my own observations. As will be seen by the annexed table the species divide themselves very naturally into three groups according to the form of the mentum. The more nearly we approach the Pacific the more acute does the cupule of the mentum become at its hinder angle and as a general rule less deep in its concavity. On the eastern slope the mentum is broader, the cupule deeper and at the posterior portion notched to the bottom. Two California species have decidedly fossorial legs, the tibiæ being broader and shorter and the tarsi very short and compressed. These two (Schaumii and angularis) I found very frequently in ants' nests and in one instance apparently eating the pupæ. Several times I have seen large black ants dragging specimens of Schaumii along the surface of the ground toward their nests and on examination have frequently succeeded in obtaining from nests specimens that had previously been dragged there. Why these insects are found with ants is a question to which $I$ am not prepared to give a definite answer, unless as I suspect the fossæ at the anterior angles and the finely punctured and apparently perforated patches under the hind angles are glandular and yield some secretion grateful to the ants.

The following table gives the result of a short study.

Mentum plate acutely angulate behind.

Anterior tarsi with last two joints rather suddenly thicker.

Teeth of anterior tibiæ distinct; hind angles of thorax moderately 
Teeth of anterior tibiæ obsolete; hind angles of thorax very feeble.... depressus, n. sp.

Anterior tarsi normal.

Legs moderate, ambulatorial, tarsi as long as tibiæ and only very feebly compressed.

Shining species; apical angle of anterior tibiæ prolonged.

Thoracic dise with deep groove on each side: hind angles spiniform saucius, Lee.

Thorax not grooved angles nodiform nitens, Lec.

Opaque species; apical angle not longer than upper tooth. Head and thorax glabrous .............................. Knochii, Lee. Head and thorax pilose pilosicollis, n, sp.

Legs short, compressed, decidedly fossorial, tarsi short, not as long as tibiæ, strongly compressed, claws small.

Hind angles limited within by an impressed line.......angularis, Lee.

Hind angles not limited within ; legs hairy............... Schaumii, Lec. Mentum plate subacute behind and with a slight notch.

Thorax suddenly constricted at base; hind angles nodiform variolosus, Kby.

Thorax not suddenly constricted at base; angles sub-acute and prominent. squammulosus, Lec

Mentum plate transversely oval, deeply notched behind.

Surface opaque.

Anterior angles with a notch on anterior margin only..canaliculatus, Kby.

Anterior angles limited within and behind by an incisure, nodi-

form castaneæ, Knoch.

\section{Surface shining.}

Anterior angles nodiform, without lateral incisure

Harrisii, Kby .

The first three species have a short frontal carina joining the reflexed edge in front, while the first two have the sides of the head also carinate and a transverse occipital groove and the pygidium elevated longitudinally. The two species just cited are very decidedly ambulatorial from the form of their legs which are relatively longer than any others of the genus. The anterior tibiæ are slender, slightly arcuate and the teeth of the outer edge small or obsolete. The tarsi are longer than the tibiæ aud the anterior pair with the peculiar formation indicated in the table. The dorsum of the elytra is also perfectly flat and bounded laterally by a slightly elevated border.

c. depressus, n. sp.-Black feebly shining. Head sparsely punctured with short carina at middle of clypeus and a lateral carina extending from the oceiput where it is higher, to the reflexed clypeal margin; occiput with transverse groove. Thorax one-fourth broader than long, broadest at anterior thircl, sides strongly rounded in front gradually narrowed to base; anterior angles moderately prominent, limited behind by a slight suleus in the lateral margin; hind angles not prominent, limited within by a slight sulcus parallel with the mar' gin; basal margin lobed at middle; disc coarsely punctured and with a shallow median suleus deeper and broader behind. Elytra flat, dise limited by 
slight elevation, sides slightly convergent behind, surface punctured with elongate shallow foveæ, at the sides rounder. Terminal spiracle feebly prominent. Pygidium sparsely foveate and subcarinate at middle. Body beneath more shining, sparsely foveato-punctate; sides of prothorax with distant strigæ Legs slender, anterior tibiæ slightly areuate, teeth obtuse nearly obsolete. Length .66 inch; $17 \mathrm{~mm}$,

Two specimens taken by Mr. Gabb, in California, probably in the southern end of Tulare Valley.

Closely allied to planatus, which has the hind angles of the thorax prominent and smooth, and the teeth of the tibiæ acute. The fourth anterior tarsal joint is suddenly broader than the preceding and equals twice its breadth. The anterior edge of the mentum plate is thicker and in the concavity more coarsely punctured.

C. pilosicollis, n. sp.-Black, opaque. Head convex, coarsely punctured and clothed with long black erect hairs. Thorax moderately convex, densely and coarsely punctured and clothed with long black erect hairs; anterior margin truncate at middle, rather suddenly sinuate within the anterior angles which are moderately prominent; sides rounded and slightly sinuate near the hind angles which are moderately prominent, acute and limited within by a faint groove. Elytra slightly convex, parallel, surface with coarse deeply impressed punctures, and sparsely pilose. Last spiracle moderately prominent. Pygidium convex with coarse foveæ and long hairs. Body beneath coarsely punctured and sparsely hairy. Mentum with an obtuse point behind. Length .44 inch; $11 \mathrm{~mm}$.

This species greatly resembles angularis. but is more convex and clothed with much longer hairs. The main difference between the two species is in the form of the tarsi and tibiæ of which mention has already been made.

One specimen from northwestern California, collected by Mr. Gabb.

C. angularis, Lec.=armatus, Walker, Nat. in Vancouver II, 320,

I have specimens of the latter species taken in an adjacent region. It is greatly to be regretted that the above paper by Mr. Walker, was ever allowed to be placed in print, for besides the absolutely valueless descriptions, scarcely one species in ten (if as many) is really new, the large number being well known common species, some having been described by Eschscholtz and Mannerheim more than twenty-five years ag .

\section{XYLOBIUS, Latr.}

X. cylindriformis, n. sp.-Cylindrical, slightly narrowed posteriorly, shining. Head convex, coarsely punctured, black; clypeus and anterior margin of front rufous. Antennæentirely rufous. Thorax slightly broader than long. somewhat narrower in front, very convex, coarsely punctured, at base a slight impression on each side of scutellum; color black, apex and base margined with rufous, also the sides but very narrowly; hind angles acute not divergent, em- 
bracing the elytra at base and stronly carinate. Elytra cylindrical, feebly narrowed behind obtusely rounded at apex, surface with striæ of moderately coarse punctures, intervals with a single row of finer punctures; color piceous, entire limb, suture and scutellum rufous. Body beneath-thorax black entirely margined with rufous, pectus black, abdomen and legs rufous ; surface coarsely punetured. Length .20 inch; $5 \mathrm{~mm}$.

Resembles very closely the figure given by Duval of $X$. alni, of Europe, but differs in the sides of the thorax being gradually but feebly rounded from tip of angles to apex and not sinuate. Specimens of $X$. alni, are unknown to me and I am not able therefore to institute more careful comparison.

I have seen two specimens from California, one in my cabinet and another in that of Mr. Ulke.

CLERUS, Geoffr.

C. (Thanasimus) repandus, n. sp.-Head black, densely punctured and sparsely clothed with erect black hairs. Antennæ black. Thorax scarcely wider than the head, strongly constricted at base and with apical impression deep; surface coarsely punctured sparsely clothed with greyish recumbent and erect black hairs; color red or yellowish-red, margined at apex with black. Elytra parallel, twice as long as wide, at basal two-fifths coarsely and deeply punctured, apical three-fifths densely and finely punctured; color and vestiture-basal two-fifths red, similar in color to the thorax, sparsely clothed with erect black hairs; apical three-fifths black, clothed with short black recumbent hairs and crossed at one-fourth from the apex by a narrow pale band the anterior margin of which is simply arcuate, the posterior sinuate and densely clothed with recumbent whitish hairs. Body beneath red, legs black. Length $.28-.36$ inch ; $7-9 \mathrm{~mm}$.

Closely allied to trifasciatus, but differs in the black head and the narrower pale band near the apex of the elytra. The line of union of the red and black portions of the elytra, is trisinuous and with a narrow border of pale pubescence. The anterior margin of the hinder pale band is nearly a true are and not sinuate, the hinder margin is nearly parallel with the anterior but extends also slightly along the suture. The sculpture and form resemble that of trifasciatus.

Occurs from northern California to Sonora.

HYDNOCERA, Newm.

H. albocincta, n. sp.-Pale brownish testaceous, subopaque, sparsely clothed with silvery white semi-erect hairs. Head sparsely punctured; antennæ testaceous. Thorax slightly longer than broad, truncate at apex and base, with transverse impressed line behind apex; sides strongly rounded in front, rather suddenly sinuate and narrowed to base. Elytra entirely covering the abdomen, very coarsely and densely perforato-punctate, with narrow transverse white band slightly behind the middle and a smaller spot near the suture intermediate between the median and a subhumeral band; color pale brownish testaceous, darker behind the median band. Body beneath similar in color to the upper surface, abdomen brown. Jegs testaceous, tibiæ brownish. Length .12 inch; $3 \mathrm{~mm}$. 
A very slender species more elongate than unifasciata, which it otherwise resembles in form. Its elytra are more coarsely punctured than any species in our fauna, and may be readily known by the color and the white markings.

Specimens were collected by Mr. G. W. Belfrage, at Waco, Texas.

SCOTODES, Esch.

Within a few days I have received from Europe types of ' $S$. annulatus, Esch., and find on careful comparison that the genus established by me for our species, Anelpisius, must be suppressed. At the time (Trans. Ent. Soc. June, 1870 , p. 88) I stated that Scotodes, was unknown to me in nature, and as but one species was known from Russia and the figure by Duval indicated an insect so different from our own, I felt justified in assigning provisional differences with the hope of having comparisons made and characters of more moment noted.

Not only do the genera agree but the species also are very clsoely allied. As compared with annulatus our species has a broader thorax not sinuate on the sides and the hind angles consequently less distinct, the elytra are punctured at the apex and become gradually more scabrous toward the base. In both species the elytra are clothed with similar pubescence, arranged in our species in two tranverse bands (at middle and at apical three-fourths) and in annulatus, in three. The sculpture in the latter species is similar over the entire surface and is not coarsely scabrous. Hind tibiæ arcuate, americanus $\delta$; straight in annulatus $\delta$.

Scotodes americanus, Horn.

Anelpistus americanus, Horn, Trans. Ent. Soc. 1870, p. 88.

The type of Scotodes annulatus, Esch., was kindly presented by Mr. Alex. Fry, of England.

TRIPLAX, Payk.

T. (Tritoma) aulica, n. sp - Ovate, shining; head and thorax above, and beneath, legs and humeral spot yellow; body beneath black, tips of abdomen yellowish. Head and thorax sparsely punctured. Antennæ yellow, club black third joint equal nearly to the three following. Elytra black, humeral spot yellow, surface with striæ of fine punctures, intervals finely punctulate. Body beneath sparsely punctulate. Tibiæ moderately dilated. Length .12-.18 inch; $3-4.5 \mathrm{~mm}$.

The humeral spot is moderate in size and similar to that of humeralis, involving the epipleuræ and extending inwards slightly within the third stria and somewhat pointed behind. It is the only species in our fauna with yellow thorax and humeral spot together.

Specimeus in my cabinet were collected and kindly presented by Dr. S. V. Summers, of St. Louis, Missouri. 


\section{$P L A T E \quad I V$.}

Figure 1. Meristhus texanus, Horn.
“ 2. Meristhus cristatus, Horn.
“ 3. Coptostethus americanus, Horn.
“ 4. Cryptohyphus perplexus, Horn. Humeral spot reddish.
“ 5. Elater Behrensi, Horn. Elytra reddish-yellow, apex black.
“ 6. " cordifer, Lec. Elytra reddish-yellow; cordiform spot black.
“ 7. " cordatus, Horn. Elytra reddish-yellow, cordiform spot black.

“ 8. Drasterius grandicollis, Horn. Color ochraceous.

“ 9. Megapenthes Rogersi, Horn. Thorax black, elytra reddish, dotted

spaces black.

" $10 . \quad$ " stigmosus, Lec. Thorax black, elytra black,

"11. "var, caprella spots yellow.
var. caprella, Lec. Thorax black, elytra black, spaces yellow.
"12. " elegans, Horn. Thorax black, post. angle yellow; elytra black, spaces reddish.

“ 13. Ludius Lecontei, Horn. Entirely black.

“ 14. Limonius Ulkei, Horn. Thorax black; elytra red, suture near apex blackish.

" 15. " mirus, Lec. Thorax black; elytra red, apex black.

" 16. " quadrimaculatus, Horn. Thorax black; elytra black, spots red.

" 17. " maculicollis, Motsch. Entirely black; margin of thorax testaceous.

“ 18. Corymbites trapezium, Lec. Entirely blacek.

" 19. " umbripennis, Lec. Thorax black; elytra yellowish

" 20. " triundulatus, Rand. Thorax black

, elytra yellowish,

" 21. " longicornis, Horn. Thorax black; hind angles yellow;

- elytra yellowish, stripes black.

“22. " " hamatus, Say. Yellowish, apical dotted portion blackish.

“ 23. “ appressus, Rand. Thorax red, disc black; elytra yellow, markings blackish.

“ 24. Oxygonus obesus, Say. Thorax black; elytra reddish.

Tarsal claw seen beneath. 

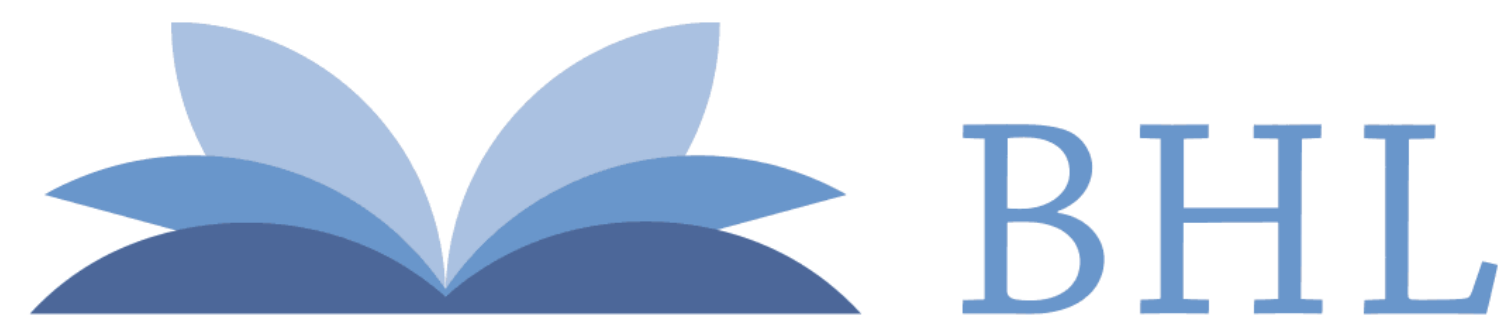

\section{Biodiversity Heritage Library}

Horn, George H. 1871. "Descriptions of new Coleoptera of the United States, with notes on known species." Transactions of the American Entomological Society 3, 325-344.

View This Item Online: https://www.biodiversitylibrary.org/item/32422

Permalink: https://www.biodiversitylibrary.org/partpdf/21859

\section{Holding Institution}

Smithsonian Libraries

\section{Sponsored by}

Smithsonian

\section{Copyright \& Reuse}

Copyright Status: NOT_IN_COPYRIGHT

This document was created from content at the Biodiversity Heritage Library, the world's largest open access digital library for biodiversity literature and archives. Visit BHL at https://www.biodiversitylibrary.org. 